\title{
Jugoslaviens undergång. Krigen, freden, framtiden 1991-2017
}

\author{
Sanimir Resic \\ Lund: Historiska media 2018 \\ 525 sider. ISBN 9789175454078
}

Omtalt av Svein Mønnesland (professor emeritus i slaviske språk, Universitetet i Oslo, sveinmon@ilos.uio.no)

Sanimir Resic er dosent i historie ved Lunds universitet. Tidligere har han utgitt Balkans historia, i denne boken tar han for seg den turbulente perioden fra Jugoslavias oppløsning til dagens situasjon i de syv etterfølgerstatene. Selv om svært mange bøker er skrevet om dette temaet, skiller denne seg ut av flere grunner. Den er skrevet av en forfatter som kjenner språket og kulturen, men som samtidig ser begivenhetene utenfra og med en faghistorikers perspektiv. Dessuten inneholder den en rekke interessante synspunkter og grundige analyser.

I tillegg til hovedkapitlene om krigene på 1990-tallet og etterfølgerstatene er det egne kapitler om krigsforbrytere, religion og EU. Som seg hør og bør i en forskningsbasert bok er det rikelige kildehenvisninger. I liten grad behandles eldre historie. Dette kan være en svakhet, for man kan ikke forvente at alle lesere skal kjenne hans tidligere bok om Balkans historie eller ha tilsvarende kunnskap. Mange av de aktuelle konfliktene kan imidlertid ikke forstås uten historisk bakgrunn, og i enkelte tilfeller gir da også forfatteren nødvendig orientering om bakgrunnen.

Den første delen omhandler krigsårene 1991-95. Her omtales alle viktige begivenheter, med den innsikt som ettertidens forskning, krigsforbryterdomstolens dokumentasjon og andre kilder gir. Forfatteren nøyer seg imidlertid ikke bare med fakta, han gir inngående analyser og personlige vurderinger, alltid med overbevisende logikk. Han er svært kritisk til det internasjonale samfunnets opptreden. Vestlige politikere forsto ikke hva som skjedde, og de var ikke interessert $\mathrm{i}$ handling. Som i andre bøker om krigen på 90-tallet nevnes Thorvald Stoltenberg bare i én setning, noe som står i motsetning til den rollen man i Norge tror han spilte. Bildt får derimot mye omtale, stort sett negativ.

Den manglende vestlige forståelsen mener forfatteren kom til syne allerede under tidagerskrigen i Slovenia i 1991. Milošević unnlot å tvinge Slovenia i kne fordi han planla en storserbisk løsning: «Det innebar att de europeiska politikerna och diplomaterne som besökte de stridande parterna för att försöka finna en 
fredlig lösning hade blivit lurade och i praktiken fungerat som Miloševićs budbärare» (s. 43). At omverdenen ikke reagerte på ødeleggelsen av Vukovar senere samme år, ser forfatteren som skjebnesvangert: «Slutsatsen blev att det var fritt fram att fortsätta eftersom ingen hade reagerat eller inngripit under Vukovars totalförstörelse" (s. 56). Og fortsettelsen kom i Bosnia. «När kriget bröt ut i Bosnien några månader senare hamnade EG:s ledande stater i ett tilstånd av förlamning som höll i sig i mer än två år» (s. 87). Passivitet eller tilsynelatende nøytralitet ble indirekte en støtte til angriperen. Og forfatteren er helt klar på hvem som var angriper: «Det råder inget tvivel om att man från bosniskserbisk sida hade syftet att fullständigt förinta den icke-serbiska befolkningen, särskilt muslimerna, i Bosnien» (s. 92). Også kroatenes politikk i Bosnia-Hercegovina får sterk kritikk. Omslaget kom etter massakren i Srebrenica og Clinton-administrasjonens politikk: "Det skulle snart visa sig att det var det amerikanska övertagandet av initiativet och ledningen som skulle få ett slut på de fyra år långa stridigheterna» (s. 115).

Forfatteren gir Milošević hovedskylden for Jugoslavias oppløsning. «Det råder inga tvivel om att Milošević var båda hjärnan och drivkraften bakom Jugoslaviens splittring och planen på ett Storserbien» (s. 342). Som han påpeker, er mange ikke klar over at det var Serbia som først erklærte seg selvstendig, før Slovenia og Kroatia, allerede i september 1990, med en forfatning som stilte Serbias lover over de føderale (s. 54).

Skildringen av krigsårene inneholder mye stoff, også en del nytt, men det kunne vært disponert mer pedagogisk. En som ikke er inne i problematikken, kan nok ha vansker med å fordøye alt, kompakt som det er. Selv en som kjenner stoffet, får lyst til å lage undertitler og systematisere det bedre.

Mest nytt stoff finner vi i kapitlet som omhandler etterfølgerstatene. En opplagt fordel er at fremstillingen er så oppdatert, ja nesten for oppdatert, for i skildringen av etterfølgerstatene ligger tyngdepunktet på det som skjedde i 2016-17, mens det som foregikk tidligere, får mindre plass. Dette ser man også av den lange listen over avis- og nyhetsartikler, for øvrig en viktig kilde for forfatteren, hvor det fremgår at han har finlest media disse to årene. Men ikke alle etterfølgerstatene er like fyldig presentert. Slovenia er nesten ikke behandlet, ingen navn på politikere eller partier nevnes. Det er først og fremst forholdet mellom serbere, kroater og bosniaker som interesserer ham.

Det er stort sett et dystert bilde forfatteren gir av statene i dag. De er preget av korrupsjon, kriminalitet, skyhøy arbeidsløshet blant unge og brain-drain. Utviklingen «domineras av nationalism, mytbildning, historieförnekelse och hämndkänslor» (s. 430). Det er få spor av forsoning. Tvert imot har forholdet mellom Serbia og Kroatia blitt forverret. Kosovo er et uløst problem, og i Bosnia-Hercegovina truer Dodiks serbiske nasjonalisme med å sette staten over styr. Ja, forfatteren sier rett ut at han tror det kan bli ny krig: "Jugoslavens öde 1991 är $\mathrm{i}$ färd att upprepas $\mathrm{i}$ våra dagars Bosnien» (s. 430). Igjen opplever han passivitet fra EU. 


\section{2 | SVEIN MØNNESLAND}

Boken inneholder svært mye viktig stoff, men enkelte konflikter behandles ikke eller kun rent overflatisk. Noen eksempler er konflikten mellom Slovenia og Kroatia om grenselinjen i Piranbukten, den skandaløse konkursen til det kroatiske landbruksfirmaet Agrokor, den opprivende språkstriden og kirkestriden i Montenegro eller problemene i Serbias provinser Vojvodina og Sandžak.

Siden litteraturmengden om Jugoslavia er så enorm, kan man ikke forvente at en forfatter skal ha med alt. Resics litteraturliste er omfattende, men en del verk savnes, for eksempel et par skandinaviske, som Tea Sindbæk Andersen, Usable History? Representations of Yugoslavia's Difficult Past from 1945 to 2002 (2012) og Kjell Arild Nilsen, Milošević i krig og i Haag. En dokumentasjon (2007).

Konklusjonen er at dette er en viktig bok - på over 500 tettskrevne sider - som gir grunnleggende informasjon om konfliktene etter Jugoslavias oppløsning og situasjonen i de syv etterfølgerstatene. Den kan anbefales både til alle som (tror de) kjenner Jugoslavia-konflikten og alle som ønsker å sette seg inn i dette tragiske kapitlet av nyere europeisk historie. 